\title{
Total phenolic and flavonoid contents and antioxidant, anti-inflammatory, analgesic, antipyretic and antidiabetic activities of Cordia myxa L. leaves
}

Enas R. Abdel-Aleem, Eman Z. Attia, Fatma F. Farag, Mamdouh N. Samy *id and Samar Y. Desoukey

\begin{abstract}
Background: Many plants of genus Cordia are traditionally used as astringent, anti-inflammatory, anthelminthic, antimalarial, diuretic, febrifuge, appetite suppressant and cough suppressant and to treat urinary infections, lung diseases and leprosy. The aim of the study is to determine the total phenolic and flavonoid contents of total ethanol extract and different fractions of C. myxa L. leaves, in addition to evaluation of some pharmacological activities including antioxidant, anti-inflammatory, analgesic, antipyretic and antidiabetic effects.
\end{abstract}

Methods: Air dried powder of C. myxa leaves were extracted using 95\% ethanol and fractionated successively with petroleum ether, dichloromethane, ethyl acetate and finally with $n$-butanol. The fractions were concentrated and then investigated for their antioxidant, anti-inflammatory, analgesic, antipyretic and antidiabetic activities using phosphomolybidinum and DPPH assays, carrageenan-induced paw edema, hot plate, yeast -induced pyrexia and streptozotocin-induced hyperglycemia methods, respectively.

Results: The ethyl acetate fraction showed the highest antioxidant activity with high phenolic and flavonoid contents $(31.03 \pm 0.15 \mathrm{mg}$ gallic acid equivalent/g dried weight and $811.91 \pm 0.07 \mathrm{mg}$ rutin equivalent/g dried weight, respectively). Dichloromethane and ethyl acetate fractions exhibited higher anti-inflammatory activity with percentages of inhibition $45.16 \%$ and $40.26 \%$, respectively, which were quite comparable to that of indomethacin (51.61\%). The petroleum ether and dichloromethane fractions showed the highest analgesic activity with reaction time $289.00 \pm 3.00$ and $288.33 \pm 20.82$, respectively. Evaluation of antipyretic activity revealed that the total ethanol extract and different fractions showed high antipyretic activities after $2 \mathrm{~h}$, which were very close to that of the standard acetyl salicylic acid with a rapid onset $(30 \mathrm{~min})$. The total ethanol extract and the petroleum ether fraction exhibited the most potent hypoglycemic effect with a significant reduction in blood glucose level especially after $3 \mathrm{~h}$ to $95.67 \pm 5.77 \mathrm{mg} / \mathrm{dl}$ and $87.67 \pm 10.26 \mathrm{mg} / \mathrm{dl}$, respectively and percentages decrease in blood glucose level were $68.22 \%$ and $70.78 \%$, respectively.

Conclusion: Cordia myxa L. extract and fractions exhibited antioxidant, anti-inflammatory analgesic, antipyretic and antidiabetic activities which may be attributed by the presence of active phytoconstituents.

Keywords: Boraginaceae, Cordia myxa, Total phenolics, Total flavonoids, Antioxidant, Anti-inflammatory, Analgesic, Antipyretic, Antidiabetic

\footnotetext{
* Correspondence: mamdouhnabil.2006@yahoo.com;

mamdouh.eskandr@mu.edu.eg

Department of Pharmacognosy, Faculty of Pharmacy, Minia University, Minia,

Egypt
} 


\section{Background}

Boraginaceae (borage) family comprises about 2740 species distributed in 148 genera [1]. Various chemical constituents isolated and characterized from Boraginaceous plants, including pyrrolizidine alkaloids, naphthaquinones, flavonoids, terpenoids, triterpenoids and phenols [2]. Cordia is an important and representative genus of this family that could grow as trees, shrubs or sometimes subscandents [1]. The generic name honours a sixteenth century botanist, Valerius Cordus [3]. The genus Cordia originates from tropical and subtropical regions. About 300 species have been identified worldwide, mostly in the warmer regions. Cordia myxa (Syn. Cordia obliqua, Cordia crenata) is a medium sized deciduous tree about $10.5 \mathrm{~m}$ [4]. The chemical characteristics of this genus are the presence of quinones which are known as cordiaquinones [1]. Pyrrolizidine alkaloids are generally present as esters. More than 200 pyrrolizidine alkaloids have been isolated from these plants. Although these alkaloids are cytotoxic and cause poisoning, Cordia myxa was reported to contain the nontoxic alkaloid macrophylline [2].

The plant parts like fruits, leaves, stem bark, seeds and roots of most species of this genus, especially Cordia dichotoma, C. myxa, C. verbenacea, C. martinicensis, C. salicifolia, C. spinescens, C. latifolia, C. ulmifolia, among others, have long been used in traditional medicine as astringent, anti-inflammatory, anthelminthic, antimalarial, diuretic, febrifuge, appetite suppressant and cough suppressant and to treat urinary infections, lung diseases and leprosy. Cordia myxa fruits and seeds are also used as expectorants and effective in treating the diseases of the lungs. Raw fruits contain a gum which can be used beneficially in gonorrhea. They can remove pain from the joints and the burning of the throat, effective in treating the diseases of the spleen, and are used as a demulcent in southern Iran [1]. For this reasons the current study evaluate some pharmacological activities of total ethanol extract and different fractions of C. myxa L. leaves including antioxidant, anti-inflammatory, analgesic, antipyretic, antidiabetic and antimalarial effects.

\section{Methods}

\section{Plant material}

The leaves of C. myxa were collected from May to November 2015 from El-Orman botanical garden, Cairo, Egypt and identified by Prof. Dr. Nasser Barakat, Professor of Botany, Faculty of Science, Minia University. A voucher sample (Mn-Ph-Cog-023) was kept in the Herbarium of Pharmacognosy Department, Faculty of Pharmacy, Minia University, Minia, Egypt.

\section{Preparation of the extract and fractions}

The air dried powdered leaves $(4.24 \mathrm{Kg})$ of C. myxa. Were extracted by maceration with $95 \%$ ethanol at room temperature with occasional agitation for 7 days till exhaustion, and then concentrated under reduced pressure till dryness. The concentrated ethanol extract $(275 \mathrm{~g})$ was suspended in the least amount of distilled water, transferred to a separating funnel and partitioned successively by liquid/liquid extraction with petroleum ether, dichloromethane, ethyl acetate and finally with $n$ butanol. The fractions were concentrated under reduced pressure at $40{ }^{\circ} \mathrm{C}$ to afford petroleum ether $(107 \mathrm{~g})$, dichloromethane $(13.2 \mathrm{~g})$, ethyl acetate $(11.74 \mathrm{~g})$ and $n$-butanol (49.92 g) fractions.

\section{Animals}

The animals used in this study include female and male albino rats weighing $200 \pm 50 \mathrm{~g}$ and mice weighing $30 \pm$ $5 \mathrm{~g}$, obtained from animal house of Faculty of Medicine, Assiut University. They were housed under standardized environmental conditions, and fed with standard diet and water. The study was conducted following approval by the Institutional Animal Ethical Committee of Faculty of Pharmacy, Minia University, Minia, Egypt.

\section{Acute toxicity}

The acute toxicity of the total ethanolic extract of Cordia myxa leaves was evaluated by measuring the lethal dose for $50 \%$ of the laboratory animals $\left(\mathrm{LD}_{50}\right)$ [5]. Different dose levels $(1,2,2.5,3$ up to $3.5 \mathrm{~g} / \mathrm{kg}$, p.o) of the total ethanolic extract (suspended in $0.5 \% \mathrm{CMC}$ ) were orally administrated to different groups of mice $(30 \pm 5 \mathrm{~g}$, each containing six mice). The control group received an equivalent dose of the vehicle $(0.5 \% \mathrm{CMC})$. Both the test and control groups were noticed for $24 \mathrm{~h}$ under normal environmental conditions, with free access to food and water.

\section{Evaluation of antioxidant study}

Each sample was dissolved in $95 \%$ methanol to make a concentration of $40 \mathrm{mg} / \mathrm{ml}$ from total ethanolic extract and different fractions except the ethyl acetate fraction which was prepared as $10 \mathrm{mg} / \mathrm{ml}$ and then diluted to prepare the series concentrations for antioxidant assays.

\section{Estimation of total phenolic content}

The content of total phenolic compounds for total ethanol extract and different fractions of $C$. myxa leaves were determined by Folin-Ciocalteu method [6]. Analysis was performed by adding $3.5 \mathrm{ml}$ of deionized water, $50 \mu \mathrm{l}$ of sample extract, $50 \mu \mathrm{l}$ Folin-Ciocalteu reagent (2 $\mathrm{N})$ and $300 \mu \mathrm{l}$ of sodium carbonate $(10 \%)$. The reaction was left for $30 \mathrm{~min}$. and then the absorbance was measured in triplicate at $730 \mathrm{~nm}$. The blank consisted of all reagents excluding the sample extract. A standard curve was made using gallic acid so that total phenolic 
Table 1 Results representing the total phenolic content of the total ethanol extract and the different fractions of C. myxa L. leaves using Folin-Ciocalteu method

\begin{tabular}{lccccc}
\hline Extract or fraction & Total extract & Petroleum ether fraction & Dichloromethane fraction & Ethyl acetate fraction & $n$-Butanol fraction \\
\hline $\begin{array}{l}\text { Total phenolic content } \\
\text { (mg/g gallic acid equivallent) }\end{array}$ & $5.76 \pm 0.23$ & $4.75 \pm 0.22$ & $8.81 \pm 0.04$ & $31.03 \pm 0.15$ & $4.54 \pm 0.04$ \\
\hline
\end{tabular}

concentration was expressed as mg of gallic acid equivalents per gram dried fraction.

\section{Estimation of total flavonoid content}

Total flavonoid content was determined following a method in literature [6], where $0.3 \mathrm{ml}$ of extracts, 3.4 $\mathrm{ml}$ of $30 \%$ methanol, $0.15 \mathrm{ml}$ of $\mathrm{NaNO}_{2}(0.5 \mathrm{M})$ and $0.15 \mathrm{ml}$ of $\mathrm{AlCl}_{3} \cdot 6 \mathrm{H}_{2} \mathrm{O}(0.3 \mathrm{M})$ were mixed. After 5 min, $1 \mathrm{ml}$ of $\mathrm{NaOH}(1 \mathrm{M})$ was added. The solution was mixed well and the absorbance was measured in triplicate against the reagent blank at $506 \mathrm{~nm}$. The standard curve for total flavonoids was made using rutin standard solution at different concentration under the same procedure. The total flavonoid content was expressed as milligrams of rutin equivalents per gram of dried fraction.

\section{Phosphomolybdate assay (total antioxidant capacity)}

The total antioxidant capacity of the fractions was determined by phosphomolybdate method using ascorbic acid as a standard [6]. An aliquot of $0.3 \mathrm{ml}$ of sample solution was mixed with $3 \mathrm{ml}$ of reagent solution $(0.6 \mathrm{M}$ sulphuric acid, $28 \mathrm{mM}$ sodium phosphate and $4 \mathrm{mM}$ ammonium molybdate). The tubes were capped and incubated in a water bath at $95^{\circ} \mathrm{C}$ for $90 \mathrm{~min}$. After the samples had cooled to room temperature, the absorbance of the mixture was measured at $695 \mathrm{~nm}$ against a blank. A typical blank contained $3 \mathrm{ml}$ of the reagent solution and the appropriate volume of the solvent and incubated under the same conditions. A standard curve was made using ascorbic acid; hence, the antioxidant activity was expressed relative to that of ascorbic acid. All determinations were done in triplicate.

\section{DPPH radical scavenging activity assay}

The free radical scavenging activity of the fractions was measured using 1,1- diphenyl-2-picryl-hydrazyl (DPPH) [6]. Briefly, $200 \mu \mathrm{l}$ of each of the extract or fractions at various concentrations was added to $2 \mathrm{ml}$ of $\mathrm{DPPH}$ solution $(0.1 \mathrm{mM})$, The reaction mixture was shaken well and incubated in the dark for $15 \mathrm{~min}$ at room temperature. Methanol was used instead of the extract and fractions as a control. Then the absorbance was measured in triplicate at
$517 \mathrm{~nm}$. The capability to scavenge the DPPH radical was calculated using the following equation:

DPPH scavenging effect $(\%)=\left[\left(\mathrm{A}_{0}-\mathrm{A}_{1} / \mathrm{A}_{0}\right) \times 100\right]$.

Where $\mathrm{A}_{0}$ was the absorbance of the control reaction and $A_{1}$ equal the absorbance in the presence of the extract. The extract concentration providing 50\% inhibition $\left(\mathrm{IC}_{50}\right)$ was calculated from the graph of $\mathrm{DPPH}$ scavenging effect against extract concentration.

\section{Anti-inflammatory activity}

The total ethanol extract and different fractions of $C$. myxa leaves were evaluated for their anti-inflammatory activity using the carrageenan-induced paw edema method [7]. Female albino rats $(200 \pm 50 \mathrm{~g})$ were randomly divided into seven groups (six animals per group). The specified dose of extract, fractions, and standard drug were suspended in $0.5 \%$ CMC solution. The -ve control group administered the vehicle $(0.5 \% \mathrm{CMC}$ solution), while the standard drug indomethacin (+ve control) was given orally at a dose level of $8 \mathrm{mg} / \mathrm{kg}$. The total ethanol extract and different fractions were administered orally at a dose of $350 \mathrm{mg} / \mathrm{kg}$ through $2 \mathrm{~h}$ after carrageenan injection $0.1 \mathrm{ml}, 1 \% \mathrm{w} / \mathrm{v}$ in normal saline, s.c.) into the sub-plantar tissue of the right hind paw. The paw thickness $(\mathrm{mm})$ was measured using a vernier calliper at $0,0.5,1,2,3,4$ and $5 \mathrm{~h}$ after administration of the tested extract, fractions and standard drug. The percentage inhibition of the rat paw edema was calculated as follows [8]:

$$
\% \text { Inhibition }=\frac{(\text { Control mean }- \text { treated mean })}{\text { Control mean }} \times 100
$$

\section{Analgesic activity}

The analgesic activity of the total ethanol extract and different fractions of $C$. myxa L. leaves was evaluated using hot plate method [9]. Mice $(30 \pm 5 \mathrm{~g})$ were grouped into seven groups (six animals each). The -ve control group administered the vehicle $(0.5 \% \mathrm{CMC}$ solution) and the standard drug paracetamol $100 \mathrm{mg} / \mathrm{kg}$, p.o. (+ve control). The tested extract and different fractions were

Table 2 Results representing the total flavonoid content of the total ethanol extract and the different fractions of $C$. myxa L. leaves

\begin{tabular}{llcccc}
\hline Extract or fraction & Total extract & Petroleum ether fraction & Dichloromethane fraction & Ethyl acetate fraction & $n$-Butanol fraction \\
\hline $\begin{array}{l}\text { Total flavonoidal content } \\
\text { (mg/g rutin equivallent) }\end{array}$ & $192.24 \pm 0.33$ & $13.09 \pm 0.11$ & $295.45 \pm 0.13$ & $811.91 \pm 0.07$ & $84.29 \pm 0.017$ \\
\hline
\end{tabular}


Table 3 Results of the total antioxidant capacities of the total ethanol extract and the different fractions of C. myxa L. leaves using phosphomolybdate assay

\begin{tabular}{lccccc}
\hline Extract or fraction & Total extract & Petroleum ether fraction & Dichloromethane fraction & Ethyl acetate fraction & Butanol fraction \\
\hline Free radical scavenging activity & $24.50 \pm 0.37$ & $26.35 \pm 0.31$ & $27.05 \pm 0.28$ & $103.40 \pm 0.05$ & $12.58 \pm 0.60$ \\
\hline
\end{tabular}

suspended in $0.5 \% \mathrm{CMC}$ solution and were administered orally at a dose level of $350 \mathrm{mg} / \mathrm{kg}$. The animals were placed on a hot plate and the temperature of the metal surface was maintained at $54{ }^{\circ} \mathrm{C}$. The time $(\mathrm{sec})$ of the response produced by the animal as tail withdrawn, licking paws or jumping due to radient heat is noted and recorded at $0,0.5,1,2,3,4$ and $5 \mathrm{~h}$ after the administration of the tested extract, fractions and the standard drug.

The percentage of protection against thermal stimulus was calculated as follows [10]:

$$
\begin{aligned}
& \text { \%protection against thermal stimulus } \\
& =\frac{\text { Test mean }(\mathrm{Ta}) \text {-Control mean }(\mathrm{Tb})}{\text { Control mean }(\mathrm{Tb})} \times 100
\end{aligned}
$$

\section{Antipyretic activity}

The total ethanol extract and different fractions of $C$. myxa L. leaves were evaluated for their antipyretic activity using yeast-induced pyrexia method $[11,12]$. The test was performed on female albino rats $(200 \pm 50 \mathrm{~g})$ by subcutaneous injection (in the back, below the nape of the neck) of $20 \%$ aqueous suspension of yeast in a dose of $10 \mathrm{ml} / \mathrm{kg}$ to induce pyrexia. The pyretic animals were grouped into seven groups (six animals each). The -ve control group orally administered the vehicle $(0.5 \%$ $\mathrm{CMC}$ solution), while the +ve control was given the reference drug acetylsalicylic acid at a dose level of 330 $\mathrm{mg} / \mathrm{kg}$, p.o). The tested extract and different fractions were suspended in $0.5 \% \mathrm{CMC}$ solution and were administered orally at a dose level of $350 \mathrm{mg} / \mathrm{kg}$ through $2 \mathrm{~h}$ after yeast injection. The rectal temperature of each animal was recorded by inserting a thermometer $2 \mathrm{~cm}$ into the rectum at $0,0.5,1,2,3,4$ and $5 \mathrm{~h}$ following the administration of the tested extract, fractions and the reference drug.

\section{Anti-diabetic activity}

The total ethanol extract and different fractions of $C$. myxa L. leaves were evaluated for their anti-diabetic effects using streptozotocin-induced hyperglycemia method [12]. The test was performed on adult male albino rats $(200 \pm 50 \mathrm{~g})$ by intraperitoneal injection of streptozotocin $(80 \mathrm{mg} / \mathrm{kg})$. Blood glucose level was measured after 3 days up to 1 week for assessment of hyperglycemia. Rats with blood glucose level above $(200 \mathrm{mg} / \mathrm{dl})$ were considered to be diabetic and were used in this study. The diabetic rats were divided into seven groups (six rats each). The control group was administered the vehicle (0.5\% CMC solution) and the standard drug vildagliptin $50 \mathrm{mg} / \mathrm{kg}$ p.o. (+ve control). The tested extract and different fractions were suspended in $0.5 \% \mathrm{CMC}$ solution and were orally administered at a dose level of $350 \mathrm{mg} / \mathrm{kg}$. Blood glucose levels were measured at intervals of 0 (fasting), $0.5,1,2,3,4$ and $5 \mathrm{~h}$ by collecting blood samples from the tail vein (caudal vein). The percentage of change in blood glucose level was calculated by the following formula $[12,13]$ :

$$
\begin{aligned}
& \text { \%lowering of blood glucose level } \\
& =\frac{\mathrm{Wc}(\text { fasting })-\mathrm{Wt}(\text { test })}{\mathrm{Wc}(\text { fasting })} \times 100
\end{aligned}
$$

\section{Statistical analysis}

Results of all biological studies were expressed as means \pm S.E.M. One-way analysis of variance (ANOVA) followedby Dunnett's test was used to determine significance when compared to the control group. $p$ values less than $0.05,0.01$, and 0.001 were considered significant $(" p<$ $\left.0.05,{ }^{* * *} p<0.01,{ }^{* * * * *} p<0.001\right)$. Graph Pad Prism 5 was used for statistical calculations (Graph pad Software, San

\begin{tabular}{|c|c|c|c|c|c|c|}
\hline $\begin{array}{l}\text { Extract or } \\
\text { fraction }\end{array}$ & Total extract & $\begin{array}{l}\text { Petroleum ether } \\
\text { fraction }\end{array}$ & $\begin{array}{l}\text { Dichloromethane } \\
\text { fraction }\end{array}$ & $\begin{array}{l}\text { Ethyl acetate } \\
\text { fraction }\end{array}$ & Butanol fraction & $\mathrm{BHT}$ \\
\hline $\mathrm{I}_{50}$ & $\begin{array}{l}1.33 \pm 0.03 \mathrm{mg} / \\
\mathrm{ml}\end{array}$ & $1.21 \pm 0.21 \mathrm{mg} / \mathrm{ml}$ & $1.03 \pm 0.06 \mathrm{mg} / \mathrm{ml}$ & $0.03 \pm 0.01 \mathrm{mg} / \mathrm{ml}$ & $\begin{array}{l}1.28 \pm 0.10 \mathrm{mg} / \\
\mathrm{ml}\end{array}$ & $\begin{array}{l}0.96 \pm 0.03 \mu \mathrm{g} / \\
\mathrm{ml}\end{array}$ \\
\hline
\end{tabular}
Diego California, USA).

Table 4 Results of the free radical scavenging activities of the total ethanol extract and the different fractions of $C$. myxa L. leaves using DPPH assay 
Table 5 Results of the anti-inflammatory activity of the total ethanol extract and the different fractions of C. myxa L. leaves using carrageenan-induced paw edema method

\begin{tabular}{llllllll}
\hline Group & \multicolumn{7}{l}{ Thickness of the paw $(\mathrm{mm})$} \\
\cline { 2 - 7 } & $0 \mathrm{~h}$ & $30 \mathrm{~min}$ & $1 \mathrm{~h}$ & $2 \mathrm{~h}$ & $3 \mathrm{~h}$ & $4 \mathrm{~h}$ & $5 \mathrm{~h}$ \\
\hline Control (-ve) & $7.38 \pm 0.25$ & $7.25 \pm 0.29$ & $7.25 \pm 0.29$ & $7.63 \pm 0.25$ & $7.75 \pm 0.29$ & $7.75 \pm 0.29$ & $7.75 \pm 0.29$ \\
Total extract (350 mg/kg) & $7.25 \pm 0.29$ & $7.00 \pm 0.00$ & $6.50 \pm 0.41^{*}$ & $6.25 \pm 0.29^{* * *}$ & $6.00 \pm 0.41^{* * *}$ & $6.25 \pm 0.29^{* * *}$ & $6.75 \pm 0.29^{* *}$ \\
Petroleum ether fraction (350 mg/kg) & $7.25 \pm 0.29$ & $7.13 \pm 0.25$ & $6.88 \pm 0.25$ & $6.75 \pm 0.29^{* * *}$ & $6.63 \pm 0.48^{* *}$ & $6.38 \pm 0.25^{* * *}$ & $7.13 \pm 0.25^{*}$ \\
Dichloromethane fraction (350 mg/kg) & $7.00 \pm 0.00^{*}$ & $7.00 \pm 0.00$ & $6.38 \pm 0.48^{*}$ & $5.75 \pm 0.29^{* * *}$ & $4.63 \pm 0.75^{* * *}$ & $4.25 \pm 0.29^{* * *}$ & $5.63 \pm 0.48^{* * *}$ \\
Ethyl acetate fraction (350 mg/kg) & $7.38 \pm 0.25$ & $7.13 \pm 0.25$ & $6.63 \pm 0.48$ & $6.13 \pm 0.48^{* *}$ & $5.50 \pm 0.41^{* * *}$ & $4.63 \pm 0.48^{* * *}$ & $6.00 \pm 0.41^{* * *}$ \\
Butanol fraction (350 mg/kg) & $7.25 \pm 0.29$ & $7.13 \pm 0.25$ & $6.75 \pm 0.29^{*}$ & $6.50 \pm 0.41^{* *}$ & $6.38 \pm 0.25^{* * *}$ & $5.755 \pm 0.29^{* * *}$ & $6.50 \pm 0.41^{* *}$ \\
Indomethacin (8 mg/kg) & $7.25 \pm 0.29$ & $6.88 \pm 0.25$ & $5.25 \pm 0.65^{* * *}$ & $3.88 \pm 0.25^{* * *}$ & $3.75 \pm 0.29^{* * *}$ & $3.75 \pm 0.29^{* * *}$ & $5.75 \pm 0.29^{* * *}$ \\
\hline
\end{tabular}

The results are presented as the mean \pm S.E.M. (Standard error of the mean). Differences with respect to the control group were calculated using the student's Ttest $\left(* P>0.05,{ }^{* *} P<0.01,{ }^{* * *} P<0.001\right)$

\section{Results}

\section{Acute toxicity}

Concerning the safety of C. myxa L. plant, a preliminary toxicity study showed no mortality up to a dose level of $2500 \mathrm{mg} / \mathrm{Kg}$ and this was in accordance with published data which reported that both the leaves and the fruits are safe and edible in India and other countries [14, 15].

\section{Evaluation of antioxidant study \\ Estimation of total phenolic content}

The content of total phenolic compounds of the total ethanol extract and the different fractions of C. myxa L. leaves was determined by Folin- Ciocalteu method. The results were shown in Table 1 and Additional file 1.

Results were varied widely, ranging from $4.54 \pm 0.04$ to $31.03 \pm 0.15 \mathrm{mg}$ gallic acid equivalent/g dried weight. The highest amount of phenols was found in the ethyl acetate fraction $(31.03 \pm 0.15)$, followed by the dichloromethane, total extract, petroleum ether and n-butanol fractions $(8.81 \pm 0.04), \quad(5.76 \pm 0.23), \quad(4.75 \pm 0.22)$ and $(4.54 \pm 0.04)$, respectively.

\section{Estimation of total flavonoid content}

The total flavonoid content of the total ethanol extract and different fractions of C. myxa L. leaves was determined and the results were shown in Table 2 and Additional file 2, where they varied widely, ranging from $13.09 \pm 0.11$ to $811.91 \pm 0.07 \mathrm{mg}$ rutin equivalent/g dried weight. The highest amounts of flavonoids was.

found in the ethyl acetate fraction (811.91 \pm 0.07 ) followed by the dichloromethane fraction (295.45 \pm 0.13), the total extract $(192.24 \pm 0.33)$, the n-butanol fraction $(84.29 \pm 0.017)$ and lastly the petroleum ether fraction which contained remarkably lower amounts of these compounds $(13.09 \pm 0.11)$.

\section{Phosphomolybdate assay (total antioxidant capacity)}

The total ethanol extract and the different fractions of C. myxa L. leaves showed varied antioxidant capacity. The highest antioxidant capacity was displayed by the ethyl acetate fraction $(103.40 \pm 0.05) \mathrm{mg}$ of ascorbic acid equivalent/g dried weight. The other fractions and the total ethanol extract showed mild antioxidant capacities, where the butanol fraction showed the lowest capacity $(12.58 \pm 0.60) \mathrm{mg}$ of ascorbic acid equivalent/g dried fraction. The results of phosphomolybdate assay were listed in Table 3 and illustrated in Additional file 3.

\section{DPPH radical scavenging activity assay}

By analyzing the antioxidant activity of the total ethanol extract and the different fractions of C. myxa L. leaves, it was demonstrated that all showed dose-dependent antioxidant

Table 6 Results representing the percentages of edema inhibition of the total ethanol extract and the different fractions of C. myxa L. leaves

\begin{tabular}{|c|c|c|c|c|c|c|c|}
\hline \multirow[t]{2}{*}{ Group } & \multirow{2}{*}{$\begin{array}{l}\text { Dose } \\
\mathrm{mg} / \\
\mathrm{kg}\end{array}$} & \multicolumn{6}{|c|}{ Percentages of inhibition (\%) } \\
\hline & & $30 \mathrm{~min}$ & $1 \mathrm{~h}$ & $2 \mathrm{~h}$ & $3 \mathrm{~h}$ & $4 \mathrm{~h}$ & $5 \mathrm{~h}$ \\
\hline Total extract & 350 & 3.45 & 10.34 & 18.09 & 22.58 & 19.35 & 12.90 \\
\hline Petroleum ether fraction & 350 & 1.66 & 5.10 & 11.53 & 14.45 & 17.68 & 8 \\
\hline Dichloromethane fraction & 350 & 3.45 & 12 & 24.64 & 40.26 & 45.16 & 27.35 \\
\hline Ethyl acetate fraction & 350 & 1.66 & 8.55 & 19.66 & 29.03 & 40.26 & 22.58 \\
\hline Butanol fraction & 350 & 1.66 & 6.90 & 14.81 & 17.68 & 25.81 & 16.13 \\
\hline Indomethacin & 8 & 5.10 & 27.59 & 49.15 & 51.61 & 51.61 & 25.81 \\
\hline
\end{tabular}


Table 7 Results of the analgesic activity of the total ethanol extract and the different fractions of C. myxa L. leaves in mice using the hot plate method using paracetamol as a standard

\begin{tabular}{|c|c|c|c|c|c|c|c|}
\hline \multirow[t]{2}{*}{ Group } & \multicolumn{7}{|l|}{ Time (sec) } \\
\hline & $\mathrm{Oh}$ & $30 \mathrm{~min}$ & $1 \mathrm{~h}$ & $2 \mathrm{~h}$ & $3 \mathrm{~h}$ & $4 \mathrm{~h}$ & $5 \mathrm{~h}$ \\
\hline Control (-ve) & $87.00 \pm 8.32$ & $83.67 \pm 7.57$ & $80.33 \pm 4.16$ & $69.67 \pm 4.16$ & $70.00 \pm 3.61$ & $80.67 \pm 4.73$ & $81.67 \pm 3.06$ \\
\hline Total extract $(350$ mg/kg) & $75.67 \pm 11.68$ & $94.33 \pm 7.23$ & $106.33 \pm 3.06^{* * *}$ & $130.67 \pm 18.50^{* *}$ & $140.67 \pm 10.60^{* * *}$ & $128.33 \pm 21.20^{*}$ & $101.33 \pm 4.93^{* *}$ \\
\hline $\begin{array}{l}\text { Petroleum ether fraction } \\
(350 \mathrm{mg} / \mathrm{kg})\end{array}$ & $72.00 \pm 6.56$ & $100.33 \pm 4.16^{*}$ & $191.00 \pm 31.08^{* *}$ & $270.67 \pm 8.50^{* * *}$ & $289.00 \pm 3.00^{* * *}$ & $227.00 \pm 28.84^{*}$ & $99.00 \pm 10.00^{*}$ \\
\hline $\begin{array}{l}\text { Dichloromethane fraction } \\
(350 \mathrm{mg} / \mathrm{kg} \text { ) }\end{array}$ & $78.67 \pm 10.60$ & $86.67 \pm 8.08$ & $170.33 \pm 21.39^{* *}$ & $206.33 \pm 16.29^{* * *}$ & $288.33 \pm 20.82^{* * *}$ & $199.67 \pm 9.87^{* * *}$ & $89.00 \pm 13.86$ \\
\hline $\begin{array}{l}\text { Ethyl acetate fraction ( } 350 \\
\mathrm{mg} / \mathrm{kg} \text { ) }\end{array}$ & $71.00 \pm 10.58$ & $91.67 \pm 3.06$ & $107.33 \pm 11.93^{*}$ & $129.67 \pm 2.08^{* * *}$ & $139.33 \pm 5.69^{* * *}$ & $103.33 \pm 1.53^{* *}$ & $91.33 \pm 12.42$ \\
\hline $\begin{array}{l}\text { Butanol fraction (350 mg/ } \\
\mathrm{kg} \text { ) }\end{array}$ & $65.00 \pm 8.00$ & $83.33 \pm 7.37$ & $85.67 \pm 13.01$ & $74.33 \pm 5.03$ & $74.33 \pm 5.03$ & $79.67 \pm 2.03$ & $80.33 \pm 4.62$ \\
\hline Paracetamol (100 mg/kg) & $70.67 \pm 5.51^{* *}$ & $107.67 \pm 5.77^{*}$ & $311.00 \pm 19.28^{* * *}$ & $321.67 \pm 25.01^{* * *}$ & $386.33 \pm 8.08^{* * *}$ & $258.33 \pm 41.59^{* * *}$ & $122.33 \pm 15.01^{* *}$ \\
\hline
\end{tabular}

activity. Results were listed in Table 4 and illustrated in Additional file 4. The ethyl acetate fraction was the most effective $\mathrm{DPPH}$ free radical scavenger with $\mathrm{IC}_{50}$ with a value of $0.03 \pm 0.01 \mathrm{mg} / \mathrm{ml}$. The other fractions and the total ethanol extract showed higher $\mathrm{IC}_{50}$, thus lower DPPH radical scavenging activity, where the total ethanol extract exhibited the lowest DPPH radical scavenging activity with $\mathrm{IC}_{50}$ value of $1.33 \pm 0.03$ $\mathrm{mg} / \mathrm{ml}$ as compared with BHT $(0.96 \pm 0.03 \mu \mathrm{g} / \mathrm{ml})$ as a positive control.

\section{Anti-inflammatory activity}

It is obvious from Tables 5 and 6 and Additional file 5 that the percentages of edema inhibition varied within the different fractions and the total extract. A gradual increase was observed for the first $4 \mathrm{~h}$, then, the activity started to decline again. The highest anti-inflammatory activity was observed after $3 \mathrm{~h}$ in the total extract and after $4 \mathrm{~h}$ for the rest of the fractions, while the standard showed this activity after both the third and fourth hour from administration. After $3 \mathrm{~h}$, the dichloromethane fraction showed moderate anti-inflammatory activity with a percentage of inhibition (40.26\%), while, after $4 \mathrm{~h}$, both the dichloromethane and the ethyl acetate fractions showed higher anti-inflammatory activity with percentages of inhibition (45.16\%) and (40.26\%), respectively, which were quite comparable to that of indomethacin (51.61\%). The total extract and the butanol fraction showed mild inhibition of the inflammation that was increased by time to be $19.35 \%$ and $25.81 \%$, respectively, after $4 \mathrm{~h}$. On the other hand, the least activity was shown by the petroleum ether fraction throughout the $5 \mathrm{~h}$ of the experiment.

\section{Analgesic activity}

The results of the analgesic activity of the total ethanol extract and different fractions of C. myxa L. leaves revealed that the total ethanol extract and all fractions exhibited potent analgesic activity compared to the control but less than the used standard paracetamol (Tables 7 and 8 and Additional file 6). One hour from the beginning of the experiment, the total ethanol extract, petroleum ether and dichloromethane fractions significantly increased the reaction time $\left(106.33 \pm 3.06^{* * *}\right),(191.00 \pm$

Table 8 Results representing the percentage of protection against external stimulus of the total ethanol extract and the different fractions of C. myxa L. leaves using paracetamol as a standard

\begin{tabular}{|c|c|c|c|c|c|c|c|}
\hline \multirow[t]{2}{*}{ Group } & \multirow{2}{*}{$\begin{array}{l}\text { Dose } \\
\mathrm{mg} / \\
\mathrm{kg}\end{array}$} & \multicolumn{6}{|c|}{ Percentage of protection against external stimulus (\%) } \\
\hline & & $30 \mathrm{~min}$ & $1 \mathrm{~h}$ & $2 \mathrm{~h}$ & $3 \mathrm{~h}$ & $4 \mathrm{~h}$ & $5 \mathrm{~h}$ \\
\hline Total extract & 350 & 12.74 & 32.37 & 87.56 & 100.96 & 59.08 & 24.07 \\
\hline Petroleum ether fraction & 350 & 19.91 & 137.77 & 288.50 & 312.86 & 181.39 & 21.22 \\
\hline Dichloromethane fraction & 350 & 3.59 & 112.04 & 196.15 & 311.90 & 147.51 & 8.98 \\
\hline Ethyl acetate fraction & 350 & 9.56 & 33.61 & 86.12 & 99.04 & 28.09 & 11.83 \\
\hline Butanol fraction & 350 & -0.4 & 6.65 & 6.69 & 6.19 & -1.2 & -1.6 \\
\hline Paracetamol & 100 & 28.68 & 287.15 & 361.71 & 451.43 & 220.23 & 49.79 \\
\hline
\end{tabular}


Table 9 Results of the anti-pyretic activity of the total ethanol extract and the different fractions of C. myxa L. leaves using yeastinduced pyrexia method

\begin{tabular}{|c|c|c|c|c|c|c|c|}
\hline \multirow[t]{2}{*}{ Group } & \multicolumn{7}{|c|}{ Rectal temperature $\left({ }^{\circ} \mathrm{C}\right)$} \\
\hline & $\mathrm{Oh}$ & $30 \mathrm{~min}$ & $1 \mathrm{~h}$ & $2 \mathrm{~h}$ & $3 \mathrm{~h}$ & $4 \mathrm{~h}$ & $5 \mathrm{~h}$ \\
\hline Control (-ve) & $39.83 \pm 0.10$ & $39.88 \pm 0.05$ & $39.88 \pm 0.05$ & $39.88 \pm 0.05$ & $39.83 \pm 0.10$ & $39.88 \pm 0.05$ & $39.28 \pm 0.09$ \\
\hline Total extract (350 mg/kg) & $39.75 \pm 0.13$ & $\underbrace{38.63}_{* * *} \pm 0.39$ & $38.53 \pm 0.50^{* *}$ & $37.73 \pm 0.17$ & $37.65 \pm 0.13$ & ${ }_{* * *}^{37.83} \pm 0.10$ & $\begin{array}{l}38.00 \pm 0.27 \\
* * *\end{array}$ \\
\hline $\begin{array}{l}\text { Petroleum ether fraction ( } 350 \text { mg/ } \\
\text { kg) }\end{array}$ & $39.83 \pm 0.10$ & $39.20 \pm 0.60$ & $38.80 \pm 0.34$ & $37.68 \pm 0.21^{* * *}$ & $\underset{* * *}{37.60 \pm 0.08}$ & $\underset{* * *}{37.43} \pm 0.10$ & $38.08 \pm 0.41$ \\
\hline $\begin{array}{l}\text { Dichloromethane fraction }(350 \text { mg/ } \\
\mathrm{kg} \text { ) }\end{array}$ & $39.83 \pm 0.10$ & $\underset{* * *}{39.25} \pm 0.17$ & $\underset{* * *}{38.53} \pm 0.10$ & $\underset{* * *}{37.78} \pm 0.15$ & $37.63 \pm 0.13$ & $\underset{* * *}{37.60 \pm 0.08}$ & $38.88 \pm 0.47^{* *}$ \\
\hline Ethyl acetate fraction (350 mg/kg) & $39.80 \pm 0.14$ & $\underset{* * *}{38.73} \pm 0.17$ & $\underset{* * *}{38.73} \pm 0.17$ & $\underset{* * *}{37.73} \pm 0.40$ & $\underbrace{37.45}_{* * *} \pm 0.31$ & $\underset{* * *}{37.70 \pm 0.18}$ & $38.25 \pm 0.41$ \\
\hline Butanol fraction (350 mg/kg) & $39.85 \pm 0.10$ & $39.73 \pm 0.17$ & $\underset{* * *}{39.13} \pm 0.17$ & $\underset{* * *}{38.33} \pm 0.35$ & $\underset{* * *}{37.73 \pm 0.17}$ & $\underset{* * *}{37.78} \pm 0.15$ & $\underset{* * *}{38.75} \pm 0.19$ \\
\hline Acetyl salicylic acid(330 mg/kg) & $39.83 \pm 0.10$ & $\underset{* * *}{38.28} \pm 0.49$ & $\underset{* * *}{37.58} \pm 0.10$ & $\underset{* * *}{37.48} \pm 0.05$ & $37.43 \pm 0.17$ & $\underset{* * *}{37.13} \pm 0.15$ & $\underbrace{37.08}_{* * *} \pm 0.10$ \\
\hline
\end{tabular}

The results are presented as the mean \pm S.E.M. Differences with respect to the control group were calculated using the student's T-test ${ }^{*} P>0.05$, $\left.{ }^{* *} P<0.01,{ }^{* * *} P<0.001\right)$

$31.08 * \%)$ and $(170.33 \pm 21.39 *)$, respectively. After $3 \mathrm{~h}$, the petroleum ether and dichloromethane fractions showed the highest analgesic activity $\left(289.00 \pm 3.00^{* * * *}\right)$ and $\left(288.33 \pm 20.82^{* * *}\right)$, respectively. They increased the reaction time more than three times as that of the - ve control. The total extract showed moderate analgesic activity. It increased the reaction time double that of the control. The ethyl acetate and butanol fractions showed slight analgesic activities compared to other fractions.

\section{Antipyretic activity}

The results of the antipyretic activity of the total ethanol extract and different fractions of $C$. myxa L. leaves revealed that the total ethanol extract and most of the fractions exhibited a significant $(p<0.001)$ antipyretic activity up to $4 \mathrm{~h}$ (Table 9 and Additional file 7 ). After 2 $h$, the total ethanol extract, the petroleum ether, the dichloromethane and the ethyl acetate fractions showed high antipyretic activities which were very close to that of the standard acetyl salicylic acid with a rapid onset (30 min). The antipyretic activity lasted up to $4 \mathrm{~h}$. The butanol fraction showed antipyretic activity with a slower onset after $2 \mathrm{~h}$ which also lasted for $4 \mathrm{~h}$.

\section{Anti-diabetic activity}

From the mentioned results in (Tables 10 and 11 and Additional file 8) the total ethanol extract and petroleum ether fraction showed potent anti-diabetic effect with a significant decrease in blood glucose level with a rapid onset $(30 \mathrm{~min})$. Their effects were increased gradually until reaching the highest level after $3 \mathrm{~h}$, and then a gradual decline was demonstrated for the rest of experiment. The total ethanol extract and the petroleum ether fraction were the most potent. They showed a significant

Table 10 Results of the antidiabetic activity of the total ethanol extract and the different fractions of C. myxa L. leaves using streptozotocin-induced hyperglycemia method and vildagliptin as a standard

\begin{tabular}{|c|c|c|c|c|c|c|c|}
\hline \multirow[t]{2}{*}{ Group } & \multicolumn{7}{|c|}{ Blood glucose level (mg/dl) } \\
\hline & $\mathrm{Oh}$ & $30 \mathrm{~min}$ & $1 \mathrm{~h}$ & $2 \mathrm{~h}$ & $3 \mathrm{~h}$ & $4 \mathrm{~h}$ & $5 \mathrm{~h}$ \\
\hline Control (-ve) & $197 \pm 7.21$ & $214.33 \pm 5.03$ & $214 \pm 7.81$ & $212.67 \pm 19.66$ & $300.33 \pm 2.31$ & $309 \pm 4$ & $322.33 \pm 13.01$ \\
\hline Total extract $(350 \mathrm{mg} / \mathrm{kg})$ & $209 \pm 14.42$ & $136 \pm 13.45^{* * *}$ & $108.33 \pm 3.06^{* * *}$ & $99.67 \pm 1.15^{* * *}$ & $95.67 \pm 5.77^{* * *}$ & $120 \pm 1.73^{* * *}$ & $224.33 \pm 15.01^{* * *}$ \\
\hline $\begin{array}{l}\text { Petroleum ether fraction ( } 350 \\
\mathrm{mg} / \mathrm{kg} \text { ) }\end{array}$ & $211 \pm 18.33$ & $117 \pm 7.21^{* * *}$ & $107.67 \pm 4.16^{* * *}$ & $93.67 \pm 7.57^{* * *}$ & $87.67 \pm 10.26^{* * *}$ & $106 \pm 6.08^{* * *}$ & $237 \pm 13.86^{* *}$ \\
\hline $\begin{array}{l}\text { Dichloromethane fraction ( } 350 \\
\mathrm{mg} / \mathrm{kg} \text { ) }\end{array}$ & $213 \pm 16.37$ & $213 \pm 11.13$ & $163.67 \pm 15.01^{* *}$ & $121.67 \pm 3.06^{* * *}$ & $190.33 \pm 1.15^{* * *}$ & $271 \pm 3.46^{* * *}$ & $323.67 \pm 2.31$ \\
\hline $\begin{array}{l}\text { Ethyl acetate fraction }(350 \mathrm{mg} / \\
\mathrm{kg} \text { ) }\end{array}$ & $201.67 \pm 3.06$ & $205.67 \pm 5.03$ & $215 \pm 4$ & $216.33 \pm 1.15$ & $310.33 \pm 1.15^{* *}$ & $311.67 \pm 8.08$ & $312.33 \pm 4.16$ \\
\hline Butanol fraction (350 mg/kg) & $204.33 \pm 5.03$ & $215 \pm 5.29$ & $221.67 \pm 9.02$ & $268 \pm 29.44^{* * *}$ & $293.33 \pm 7.51$ & $305.33 \pm 3.51$ & $327 \pm 15.20$ \\
\hline Vildagliptin (50 mg/kg) & $208.67 \pm 7.77$ & $125 \pm 12.12^{* * * *}$ & $102.33 \pm 2.31^{* * *}$ & $94.67 \pm 6.66^{* * *}$ & $64 \pm 11.36^{* * *}$ & $85 \pm 15.20^{* * *}$ & $178 \pm 20.66^{* * *}$ \\
\hline
\end{tabular}

The results are presented as the mean \pm S.E.M. Differences with respect to the control group were calculated using the student's T-test ${ }^{*} P>0.05$,

$\left.{ }^{* *} P<0.01,{ }^{* * *} P<0.001\right)$ 
Table 11 Results representing the percentage of decrease in of blood glucose level of the total ethanol extract and the different fractions of C. myxa L. leaves using streptozotocin-induced hyperglycemia method

\begin{tabular}{|c|c|c|c|c|c|c|c|c|}
\hline \multirow[t]{2}{*}{ Group } & \multirow{2}{*}{$\begin{array}{l}\text { Dose } \\
\mathrm{mg} / \\
\mathrm{kg}\end{array}$} & \multicolumn{7}{|c|}{ Percentage of decrease in blood glucose level (\%) } \\
\hline & & $\overline{\mathrm{Oh}}$ & $30 \mathrm{~min}$ & $1 \mathrm{~h}$ & $2 \mathrm{~h}$ & $3 \mathrm{~h}$ & $4 \mathrm{~h}$ & $5 \mathrm{~h}$ \\
\hline Total extract & 350 & -6.09 & 36.54 & 49.38 & 53.13 & 68.22 & 61.17 & 30.40 \\
\hline Petroleum ether fraction & 350 & -7.11 & 45.41 & 49.69 & 55.96 & 70.78 & 65.70 & 26.47 \\
\hline Dichloromethane fraction & 350 & -16 & 0.62 & 23.52 & 42.79 & 36.56 & 12.30 & -0.42 \\
\hline Ethyl acetate fraction & 350 & -2.37 & 4.04 & -0.47 & -1.72 & -3.44 & -0.64 & 3.10 \\
\hline Butanol fraction & 350 & -3.72 & -0.31 & -3.58 & -26.02 & 2.22 & 1.19 & -1.45 \\
\hline Vildagliptin & 50 & -5.90 & 41.68 & 52.18 & 55.49 & 78.69 & 72.49 & 44.78 \\
\hline
\end{tabular}

reduction in blood glucose level especially after $3 \mathrm{~h}$

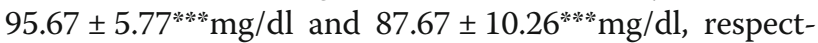
ively. Also the percentage decrease in blood glucose level was $(68.22 \%)$ and $(70.78 \%)$, respectively, which demonstrates their close resemblance to the standard vildagliptin $(78.69 \%)$. The dichloromethane fraction also showed a moderate gradual reduction in blood glucose level up to $121.67 \pm 3.06^{* * *} \mathrm{mg} / \mathrm{dl}$ after $2 \mathrm{~h}$ with a percentage decrease of $(42.79 \%)$ while both ethyl acetate and butanol fractions showed no anti-diabetic activity throughout the experiment time.

\section{Discussion}

Safety of C. myxa was evaluated and results confirmed the previous published data $[14,15]$. The ethyl acetate fraction showed the highest antioxidant activity compared to the total ethanol extract and other fractions. This activity may be attributed to its high content of flavonoids and other phenolic compounds as phenyl propanoids. The total ethanol extract and dichloromethane fraction exhibited highest anti-inflammatory activities compared to indomethacin. Many mechanisms were proved for anti-inflammatory activity of flavonoids, such as: inhibition of cyclooxygenase and 5- lipoxygenase pathways, and inhibition of eicosanoid biosynthesis, together with their ability to inhibit neutrophil degradation [16]. The potent antipyretic activity of the total extract and different fractions of C. myxa L. may be attributed to its content of flavonoids and sterols [17]. Analgesic activity may be attributed to their content of sterols which were reported to have analgesic activity [18]. Finally; the hypoglycaemic effect is in accordance with reported literature [19] for the total ethanol extract which proved that the hypoglycemic mechanism is throughout the inhibition of $\alpha$-glucosidase enzyme. Thus it can decrease blood glucose level or inhibit glucose absorption.

\section{Conclusion}

The present study confirmed that total ethanol extract and different fractions of C. myxa leaves showed significant antioxidant, antiinflammatory, analgesic, antipyretic and antidiabetic activities in different in vitro and in vivo experimental models, which are in accordance with folk medicine of many Cordia plants. The presence of high content of flavonoids and other phenolic compounds in the ethyl acetate fraction might have some role in the observed pharmacological activities. In addition, the acute toxicity does not show any symptoms, changes in behavior or mortality at $2.5 \mathrm{~g} / \mathrm{kg}$ doses that indicate a therapeutic safety for the doses pharmacologically active. The further detailed investigation is ongoing to determine the exact bioactive phytoconstituents that are responsible for those actions of this plant as traditional medicine. Moreover, it could be a potential source for discovery of antioxidant, antiinflammatory, analgesic, antipyretic and antidiabetic drug development.

\section{Additional files}

Additional file 1: Total phenolic content of the total ethanol extract and the different fractions of C. myxa L. leaves. (DOCX $26 \mathrm{~kb}$ )

Additional file 2: Total flavonoid content of the total ethanol extract and the different fractions of C. myxa L. leaves. (DOCX $27 \mathrm{~kb}$ )

Additional file 3: Antioxidant capacities of the total ethanol extract and the different fractions of C. myxa L. leaves using phosphomolybdate assay. (DOCX $22 \mathrm{~kb}$ )

Additional file 4: DPPH radical scavenging activity of the total ethanol extract and the different fractions of C. myxa L. leaves. (DOCX $150 \mathrm{~kb}$ )

Additional file 5: Anti-inflammatory effects of the total ethanol extract and the different fractions of C. myxa L. leaves using carrageenan induced paw edema method. (DOCX $94 \mathrm{~kb}$ )

Additional file 6: Analgesic effects of the total ethanol extract and the different fractions of C. myxa L. leaves using hot plate method. (DOCX 93 $\mathrm{kb})$

Additional file 7: Antipyretic effects of the total ethanol extract and the different fractions of C. myxa L. leaves using Yeast-induced pyrexia method. (DOCX $94 \mathrm{~kb}$ )

Additional file 8: Antidiabetic effects of the total ethanol extract and the different fractions of C. myxa L. leaves using streptozotocin-induced hyperglycemia method. (DOCX 96 kb)

\section{Abbreviations}

C. myxa: Cordia myxa; CMC: Carboxy methyl cellulose; DPPH: 2,2-diphenyl-1picrylhydrazyl; $I C_{50}$ : Inhibitory concentration 50; p.o.: Taken orally;

s.c: Subcutaneous 


\section{Acknowledgements}

Not applicable

\section{Authors' contributions}

ERA performed all of the experiments in the laboratory and data collection, analysis, graphical representation and interpretation. EZA did critical statistical analysis and experiments. FFF did experiment design and overall monitoring. Critical revision of the article was done by MNS. Conception, experiment design, overall monitoring and final approval of the article was done by SYD. All authors read and approved the final manuscript.

\section{Funding}

There hadn't any funding supports for carrying this research.

Availability of data and materials

Not applicable.

\section{Ethics approval and consent to participate}

The study was approved by the Institutional Animal Ethical Committee of Faculty of Pharmacy, Minia University, Minia, Egypt.

\section{Consent for publication}

Not applicable.

\section{Competing interests}

The authors declare that they have no competing interest.

Received: 8 April 2019 Accepted: 23 August 2019

Published online: 09 September 2019

\section{References}

1. Yadav R, Yadav SK. Evaluation of antimicrobial activity of seeds and leaves of Cordia obliqua wild against some oral pathogens. Indo Am J Pharm Res. 2013;3:6035-43.

2. Sharma RA, Singh B, Singh D, Chandrawat P. Ethnomedicinal, pharmacological properties and chemistry of some medicinal plants of Boraginaceae in India. J Med Plant Res. 2009:3:1153-75.

3. Hussain N, Kakoti BB. Review on ethnobotany and phytopharmacology of Cordia dichotoma. J Drug Deliver Therap. 2013;3:110-3.

4. Abdel El-Aleem ER, Seddik FE-Z, Samy MN, Desoukey SY. Botanical studies of the leaf of Cordia myxa L. J Pharmacogn Phytochem. 2017;6:2086-91.

5. Akhila JS, Deepa S, Alwar MC. Acute toxicity studies and determination of median lethal dose. Curr Sci. 2007;93:917-20.

6. Abdel-Wahab NM, El-kashef DF, Attia EZ, Desoukey SY, Elkhayat ES, Fouad MA, Kamel MS. Total phenol content and antioxidant activities of the fungus Ulocladium botrytis. J Adv Biomed Pharm Sci. 2018;1:17-9.

7. Winter CA, Risley GA, Nuss GW. Carrageenan induced edema in hind paw of the rat as an assay for inflammatory drugs. Proc Soc Exp Biol Med. 1962;111:544-7.

8. Sudjarwo ASS. The potency of piperine as anti-inflammatory and analgesic in rats and mice. Folia Med Ind. 2005:41:190-4.

9. Hosseinzadeh H, Ramezani M, Salmani G. Antinociceptive, anti-inflammatory and acute toxicity effects of Zataria multiflora Boiss extracts in mice and rats. J Ethanopharmacol. 2000;73:379-85

10. Wang Y, Chen Y, Xu H, Luo H, Jiang R. Analgesic effects of glycoproteins from Panax ginseng root in mice. J Ethanopharmacol. 2013;148:946-50.

11. Panthong A, Kanjanapoth D, Taesotikul T, Wongcome T, Reutrakul V. Antiinflammatory and antipyretic properties of Clerodendrum petasites S.Moore. J Ethanopharmacol. 2003:85:151-6.

12. Gomaa AA-R, Samy MN, Desoukey SY, Kamel MS. Antiinflammatory, analgesic, antipyretic and anti-diabetic activities of Abutilon hirtum (Lam.) Sweet. Clin Phytosci. 2018;4:11.

13. Peungvicha $P$, Thirawarapan SS, Temsiririrkkul R, Watanabe H, Prasain JK, Kadota S. Hypoglycemic effect of the water extract of Piper sarmentosum in rats. J Ethanopharmacol. 1998;60:27-32.

14. Chauhan D, Shrivastava AK, Patra S. Diversity of leafy vegetables used by tribal peoples of Chhattisgarh, India. Int J Curr Microbiol App Sci. 2014:3:611-22

15. Gupta R, Das GG. Toxicity assessment and evaluation of analgesic, antipyretic and anti-inflammatory activities on Cordia obliqua leaf methanol extract. Pharm J. 2017;9:856-61.
16. Nijveldt RJ, Nood EV, Hoorn DE, Boelens PG, Norren KV, Paul AL. Flavonoids: a review of probable mechanisms of action and potential applications. Am J Clin Nutr. 2001;74:418-25.

17. Niazi J, Gupta V, Chakarborty P, Kumar P. Anti-inflammatory and antipyretic activity of Aleuritis moluccana leaves. Asian J Pharm Clin Res. 2010;3:35-7.

18. Owoyele BV, Oguntoye SO, Dare K, Ogun biyi BA, Aruboula EA, Soladoye AO. Analgesic, anti-inflammatory and antipyretic activities from flavonoid fractions of Chromolaena odorata. J Med Plant Res. 2008;2:219-25.

19. Malik A, Ahmad AR. Antidiabetic effect of standardized extract of Indonesian Kanunang leaves (Cordia myxa L.). Int J Pharm Tech Res. 2016;9(8):268-75.

\section{Publisher's Note}

Springer Nature remains neutral with regard to jurisdictional claims in published maps and institutional affiliations.

\section{Submit your manuscript to a SpringerOpen ${ }^{\circ}$ journal and benefit from:}

- Convenient online submission

- Rigorous peer review

- Open access: articles freely available online

- High visibility within the field

- Retaining the copyright to your article

Submit your next manuscript at $\boldsymbol{\nabla}$ springeropen.com 